\title{
Series of experiments for empirical validation of solar gain modeling in building energy simulation codes - Experimental setup, test cell characterization, specifications and uncertainty analysis
}

\author{
H. Manz ${ }^{*, 1}$, P. Loutzenhiser ${ }^{1,2}$, T. Frank ${ }^{1}$, P.A. Strachan ${ }^{3}$, R. Bundi ${ }^{1}$, and G. Maxwell ${ }^{2}$ \\ ${ }^{1}$ Empa, Materials Science \& Technology, Laboratory for Applied Physics in Building, $\mathrm{CH}-$ \\ 8600 Duebendorf, Switzerland \\ ${ }^{2}$ lowa State University, Dept. of Mechanical Engineering, Ames, lowa 50011, USA \\ ${ }^{3}$ University of Strathclyde, Dept. of Mechanical Engineering, ESRU, Glasgow G1 1XJ, \\ Scotland \\ * Corresponding author (heinrich.manz@empa.ch)
}

\begin{abstract}
Empirical validation of building energy simulation codes is an important component in understanding the capacity and limitations of the software. Within the framework of Task 34/Annex 43 of the International Energy Agency (IEA), a series of experiments was performed in an outdoor test cell. The objective of these experiments was to provide a high-quality data set for code developers and modelers to validate their solar gain models for windows with and without shading devices. A description of the necessary specifications for modeling these experiments is provided in this paper, which includes information about the test site location, experimental setup, geometrical and thermophysical cell properties including estimated uncertainties. Computed overall thermal cell properties were confirmed by conducting a steady-state experiment without solar gains. A transient experiment, also without solar gains, and corresponding simulations from four different building energy simulation codes showed that the provided specifications result in accurate thermal cell modeling. A good foundation for the following experiments with solar gains was therefore accomplished.
\end{abstract}

Keywords: Building energy simulation; Empirical validation; Test cell specification

\section{Introduction}

The use of building energy simulation codes has been continuously evolving since the 1970s and 1980s. The integral approach, by which all relevant energy transport paths are simultaneously processed, makes building energy simulation codes powerful tools for the design of energy-efficient buildings, which may explain their growing popularity. Numerous commercial and freeware codes are now available with varying levels of modeling versatility, complexity and user interfaces. An overview of the theory and application of this type of tool is given by Clarke [1].

Validation of models implemented in the codes is a prerequisite for a successful application. Studies performed by Judkoff [2] and Judkoff and Neymark [3] have shown large disagreements between different codes. Code validation is therefore seen as an essential part of the development of building energy simulation software. Clarke [1] stressed this point by noting that in new code development a code that has successfully passed a validation test may fail the same test at a later time. Hence, validation checks must be made on a regular basis to guarantee the accuracy of the code. An excellent way in which to do this was proposed and performed within IEA Annex 21 [3]: a set of diagnostic tests was implemented into a software package. A similar approach was pursued by Ben-Nakhi and Aasem [4], who developed a module for integrating into simulation codes to validate transient heat flow computation through opaque multi-layered constructions.

A number of authors have been working on validation methodology $[2,5,6,7,8]$. Code checking - i.e. testing if the code behaves as expected and is basically free of programming 
errors - and documentation of the functions of each routine can be thought of as the first steps towards quality assurance and validation. Judkoff [2] provides an overview of additional validation techniques and discusses advantages and disadvantages of three different approaches, which are (i) analytical (comparison of simulation results with analytical solutions), (ii) comparative (code-to-code comparisons), and (iii) empirical (comparisons of simulation results with experimental data). The advantages of analytical and comparative tests are that there is no uncertainty associated with the input parameters and tests are relatively inexpensive to perform. The disadvantage of the analytical test is that a limited number of analytical solutions are available and that in comparative tests there is no truth standard. On the other hand, empirical validation has a truth standard within the limits of the experimental uncertainty and, in addition, complex cases can be performed. But empirical validation is the most time-consuming and expensive of the three techniques and has therefore only been performed on a very limited basis.

Highly glazed buildings are becoming increasingly popular around the world. It is particularly important to model the thermal performance of the transparent façade when predicting the thermal behavior of the building in summer. Energy flows through the glazing and shading devices are determined by optical, thermodynamic and fluid-dynamic processes [9]. Because of the complexities of the systems, no analytical solutions are available for such validations. Code-to-code comparisons are not sufficient because it is not obvious which model, if any, is correct. The only suitable approach is therefore to perform high-quality experiments for validation purposes.

The series of experiments discussed here was performed in a test cell on the Empa campus in Duebendorf, Switzerland. According to Strachan [10], test cells represent an economic and practical alternative between laboratory experiments and full-scale monitoring of buildings and provide the best available environment providing high-quality data sets needed for the empirical whole-model validation. The facility used in this study, the cell concept was first described by Simmler et al. [11], has guarded zones for thermal shielding of the cell. Compared with previous empirical validation projects using test cells without guarded zones $[10,12,13]$, the guarded zones offered much better control of boundary conditions in this study. The data acquired at the Empa facility meet all nine criteria described by Lomas et al. [13] for high-quality data sets.

The goal of this project is to provide a set of empirical data from a series of experiments. The experiments will increase in complexity and can be used for validation of window models with and without external or internal shading devices. Previous test cell empirical validation work by Moinard and Guyon [14] has shown that determining the overall thermal cell characteristics is of the greatest importance. Two experiments without solar gains were therefore performed in our work during the first phase of the project. These experiments included (i) a steady-state experiment to characterize the overall thermal performance of the cell, and (ii) a transient experiment with pseudo-random heat inputs.

Empirical validation exercises are always tests of (i) the experiment itself, (ii) the simulation tool, and (iii) the modeler. Four building energy simulation codes were used to model the transient experiment in this study. The specific codes were DOE-2.1E [15], EnergyPlus [16], ESP-r [17] and HELIOS [18]; inputs were made by different modelers. Results from those experiments, which included solar gains through a window with or without a shading device and corresponding building energy simulation code predictions, will be presented in future papers.

In empirical validation work measured and predicted uncertainty bands need to be evaluated and parameters identified to which the results are particularly sensitive. Lomas and Eppel [19] described three different sensitivity analysis techniques and its applicability to building simulation codes. Macdonald and Strachan [20] implemented algorithms for uncertainty analysis based on differential sensitivity and the Monte Carlo method into a building energy 
simulation code called ESP-r. In this paper, uncertainties are given for all measured and code input parameters as well as uncertainty bands of simulated results obtained using ESPr.

\section{Concept of test cells with guarded zones}

Details of the test cell location and orientation are shown in Table 1. The facility comprising two identical test cells was designed for calorimetric measurements on façade elements and is shown in Figure 1. Table 2 depicts the main geometrical parameters of the cell, including estimated uncertainties. The wooden structure building surrounding the cells is insulated with a layer of $0.12 \mathrm{~m}$ glass wool. Both cuboid shape cells adjoin a guarded zone at five faces (Figure 2). Each test cell and each guarded zone employs its own air conditioning unit. The temperature in the test cells is controlled by means of an air-water heat exchanger. The cooling power ( $\max .5000 \mathrm{~W}$ ) can be determined by measuring the mass flow rate and the temperature difference in the water circuit. The heating power (max. $3500 \mathrm{~W}$ ) is directly determined by measuring the electrical power. If the temperature differences between the guarded zone and cell are small, energy flows through the external wall become far greater than the flows through the remaining faces and energy flows through the external wall can therefore be measured more precisely. A PC with data acquisition equipment was located in the guarded zone and was shielded from the test cell by an airtight curtain.

The goal of the test cell ventilation (Figure 2) was to minimize the temperature stratification and to obtain a well-defined cell air temperature. Temperature stratification of cell air was smaller than $0.5 \mathrm{~K}$ in the experiments presented in this paper. Air was extracted near the ceiling, while conditioned air was supplied close to the floor at low speed by means of two large cylindrical fabric outlets. Except for locations near the extract grills, air speeds in the whole cell were below $0.1 \mathrm{~m} / \mathrm{s}$. Using one fan only, the flow rate of recirculated air was $\sim 40$ air changes per hour; this value could be increased by switching on a second fan.

Equipment for air recirculation in the guarded zone maintained a more uniform air temperature distribution. Recirculated air was supplied near the south wall of the cell by means of four large cylindrical fabric outlets that were mounted horizontally and vertically around the test cell. The air was extracted near the north cell wall to obtain a flow pattern close to a piston flow. Outer surface temperatures of the cell adjacent to the guarded zone were within a range of $2 \mathrm{~K}$ during experiments described in this paper.

To control the outside environment of all six faces of the test cell, an external chamber shown in Figures 2 and 3 was mounted at the cell's south wall. The air temperature in this chamber was controlled by a water/air heat exchanger that was connected to a thermostat apparatus. As can be seen in Figure 3, the external chamber was covered with aluminum foil that reflects solar radiation, in order to minimize the impact of solar energy in the chamber. Air temperature stratification in the exterior chamber was reduced by a fan. All outer surface temperatures of the south cell wall adjacent to the external chamber were within a band of $0.3 \mathrm{~K}$ during the experiments.

\section{Thermal properties of test cell envelope 3.1 Layer and surface properties}

Tables 3 to 5 show layer sequences, thicknesses and thermophysical properties of all layers of the cell envelope. Modelers may wish to investigate the impact of uncertainties of input parameters on their results. Estimated uncertainties of all values are therefore given. Layer number 1 denotes the first layer from the outside. Numerical values of thermophysical properties were either based on product specifications, literature data or in-house measurements. If thermophysical properties had to be based on literature data, several literature sources were employed and the mean of these was taken. 
The reflectances of samples of all relevant surfaces were measured in the wavelength interval of solar radiation ( 250 to $2500 \mathrm{~nm}$ ) at approximately perpendicular incident solar radiation using a spectrophotometer. Integral values for solar and visual reflectances were determined according to EN 410 [21] using GLAD software [22]. Emissivities were measured at room temperature using an integral method. Table 6 depicts optical properties of cell surfaces.

\subsection{Thermal bridges: door, edges, etc.}

Total thermal losses - including those at edges, door, sealing at external wall and intersections of pipes or flexes with the cell envelope - were computed using TRISCO software [23]. This code enables 3D steady-state analysis of heat conduction processes. Equivalent thermal conductivities of cavities were calculated according to prEN ISO 10077-2 [24]. The final model of the test cell employed $5.6 \cdot 10^{6}$ nodes. Figures 4 and 5 show results of these simulations. High heat fluxes were computed at the sealing of the door and at the sealing between cell and removable external wall. Figure 6 shows a picture of the thermal bridges at the door taken with an infrared camera. Dark areas represent regions with higher radiation fluxes corresponding to increased surface temperatures.

Numerical values of additional thermophysical properties needed for these simulations were also based on product specifications and literature data. The total thermal conductance of the whole cell envelope from cell air to the outer surface of the cell envelope, including all flows at thermal bridges, were calculated at temperatures of $0^{\circ} \mathrm{C}$ and $20^{\circ} \mathrm{C}$ as being $13.539 \mathrm{~W} / \mathrm{K}$ and $14.721 \mathrm{~W} / \mathrm{K}$, respectively.

\subsection{Internal thermal mass}

The heat capacity of the technical equipment in the cell, which consisted of metallic ducts, grills, fans, a heat exchanger apparatus inside a metallic casing, an electrical cabinet etc. was estimated to be $200 \pm 30 \mathrm{~kJ} / \mathrm{K}$ (Fig. 1, right). Because the steel sheets were a major component of the thermal mass, the thermal response of the internal mass was assumed to be fast compared with the cell envelope. However, simulations showed that the impact of this thermal mass on the overall transient thermal behavior of the cell was rather small.

\subsection{Total steady-state thermal properties}

Tables 7 and 8 show the heat transfer coefficients $\Lambda_{i}$ and the thermal conductances $H_{i}$. These parameters refer to the heat flow between the cell air and the outer surface of the cell envelope. In all TRISCO simulations, the heat transfer resistance between cell inside air and the inner surface of the cell envelope was assumed to be $0.13 \mathrm{~m}^{2} \mathrm{~K} / \mathrm{W}$ at all locations. It can be seen in Table 7 that $35 \%$ of the heat flow between cell and guarded zone occurs at thermal bridges. Thermal conductance as a function of temperature, $\theta$ in ${ }^{\circ} \mathrm{C}$, are shown in Equations 1 and 2.

$$
\begin{array}{lll}
\text { Guarded zone: } & \mathrm{H}_{\mathrm{Gz}}(\theta)=11.877+0.0534 \cdot \theta & (\mathrm{W} / \mathrm{K}) \\
\text { Outside: } & \mathrm{H}_{\mathrm{EW}}(\theta)=1.662+0.0057 \cdot \theta & (\mathrm{W} / \mathrm{K})
\end{array}
$$

This temperature dependence is caused by the temperature-dependent thermal conductivities shown in Tables 3 to 5 . Losses at thermal bridges are almost independent of temperature as they are mainly due to heat conduction in metals which is only affected to a very minor extent by temperature changes within ranges considered here.

\subsection{Sensitivity and uncertainty of steady-state thermal properties}


The numerical accuracy of TRISCO simulations was investigated using a grid sensitivity study and was found to be below $2 \%$. The total uncertainties of the thermal conductance in Equations 1 and 2 were therefore mainly determined by the uncertainty of the input parameters. Assuming that each individual input parameter is independent of other inputs, the total or combined uncertainty $u_{c}$ can be estimated from the square root of the quadrature sum of the uncertainties due to each of the inputs shown in Equation 3.

$u_{c}=\sqrt{\sum_{i=1}^{N} u_{i}^{2}}$

Table 9 shows the impact of the uncertainties of a few parameters on the uncertainties of thermal conductance. These values were found using TRISCO simulations. Additional uncertainties occurred due to deviations of the model geometry or due to uncertainties in calculating heat transfer in cavities. Total uncertainties of thermal conductance, $\mathrm{H}_{\mathrm{Gz}}$ and $\mathrm{H}_{\mathrm{EW}}$, were assumed to be less than $\pm 8 \%$.

\section{Sensors}

All sensors were periodically calibrated according to an Empa internal quality assurance system. About 150 parameters were acquired every 4 minutes during the experiments. After each full hour of data acquisition mean values were computed for the last hour and saved.

Table 10 shows all meteorological parameters measured at the facility, the type of sensor and uncertainties according to manufacturers' specifications. Table 11 depicts specifications of the most important parameters which were measured in the test cell, the external chamber and in the guarded zone.

The locations of sensors in the test cell and in the guarded zone can be seen in Figure 7. The vertical distances of air temperature sensors inside the cell from the floor to ceiling were $0.3 \mathrm{~m}, 1.1 \mathrm{~m}$ and $2.1 \mathrm{~m}$.

\section{Airtightness of the cell}

All inner and outer cell surfaces were made of steel sheets, and the gaps between the sheets were sealed with silicone. Two-stage rubber sealings at the door and at the external wall made leak protection possible. The airtightness of the cell was measured using the blower door method. At an overpressure of $50 \mathrm{~Pa}$ in the test cell, air exchange was found to be $0.2 \mathrm{~h}^{-1}$. The thermal effects of infiltration were therefore assumed to be negligible.

\section{Experiment for steady-state cell characterization}

In addition to the computational approach described in Section 3, a steady-state experiment was performed in order to measure thermal conductances $\mathrm{H}_{\mathrm{GZ}}$ and $\mathrm{H}_{\mathrm{EW}}$ directly in the test facility. The external chamber was mounted over the external surface during these for conditioning of the sixth face of the cell. The air inside the test cell, the guarded zone and the external chamber were stirred in order to reduce temperature stratifications. Boundary condition parameters were kept as close as possible to constant values. From a steady-state analysis of the cell results:

$$
\begin{aligned}
& P_{e l, A}+H_{G Z}\left(T_{T C, A}-T_{G Z, A}\right)+H_{E W}\left(T_{T C, A}-T_{E C, A}\right)=0 \\
& P_{e l, B}+H_{G Z}\left(T_{T C, B}-T_{G Z, B}\right)+H_{E W}\left(T_{T C, B}-T_{E C, B}\right)=0
\end{aligned}
$$

Parameters determined in the experiment were the heating power $\mathrm{P}_{\mathrm{el}}$, space-averaged air temperature in the test cell $\mathrm{T}_{\mathrm{TC}}$ (8 sensors), space-averaged outer surface temperature of cell in guarded zone $\mathrm{T}_{\mathrm{GZ}}$ (25 sensors) and space-averaged outer surface temperature of cell in 
external chamber $\mathrm{T}_{\mathrm{EC}}$ (5 sensors). Because there were two unknowns, $\mathrm{H}_{\mathrm{GZ}}$ and $\mathrm{H}_{\mathrm{EW}}$, two equations, representing two different temperature boundary conditions, were needed. Indices $A$ and $B$ denote these two phases of the experiment. The solutions for $\mathrm{H}_{\mathrm{GZ}}$ and $\mathrm{H}_{\mathrm{EW}}$ were found analytically by solving this set of equations (Equations 4 and 5 ).

No ideal steady-state situation could be reached in this experiment. Higher fluctuations in boundary conditions occurred particularly on days with high solar irradiances and wide differences between daily minimum and maximum outside air temperature. Hence, time intervals with an overcast sky and, therefore, less fluctuating boundary conditions were chosen for analysis. Figure 8 shows temperatures and heating power in the cell as a function of time during phase B. To eliminate small transient effects in the cell envelope, timeaveraged values were used (Table 12). Taking into account that the uncertainties were dominated by systematic effects, the uncertainties given here were higher than uncertainties of individual sensors from information in Table 11. It was assumed that mean temperatures and heating power were independent of each other and the total uncertainty was therefore again estimated from the square root of the quadrature sum of the uncertainties due to each of the inputs (see Equation 3).

Based on this steady-state experiment and the procedure described above, numerical values and total uncertainties for the thermal conductances were calculated to be $\mathrm{H}_{\mathrm{Gz}}=12.23 \mathrm{~W} / \mathrm{K} \pm$ $0.53 \mathrm{~W} / \mathrm{K}$ and $\mathrm{H}_{\mathrm{EW}}=2.12 \mathrm{~W} / \mathrm{K} \pm 0.59 \mathrm{~W} / \mathrm{K}$. These values refer to the mean temperatures in the cell envelope of $36.6^{\circ} \mathrm{C}$ in the external wall, and, $31.6^{\circ} \mathrm{C}$ in the cell envelope adjacent to the guarded zone, occurring during this experiment. Comparison of the values found in this steady-state experiment and those determined by the numerical method described in Section 3 are depicted in Fig. 9. Uncertainty bands of the results of the two methods overlap in both cases. The uncertainty of $\mathrm{H}_{\mathrm{EW}}$ determined in the steady-state experiment was relatively large. The real value of $\mathrm{H}_{\mathrm{Gz}}$ seems to be close to the lower end of the uncertainty band computed numerically by the method described in Section 3.

\section{Transient experiment for cell characterization}

The goal of this transient experiment was to verify whether specifications given in Tables 2 , $3,4,5,7$ and 8 provide an accurate characterization for modeling transient thermal behavior of the cell. This transient experiment was configured in the same way as the steady-state experiment. Constant temperatures of approximately $23^{\circ} \mathrm{C}$ were maintained in the guarded zone and the external chamber. Fluctuations of less than $\pm 1 \mathrm{~K}$ occurred during this experiment.

Due to one constantly running recirculation fan inside the cell, there was an internal heat source of $\sim 77 \mathrm{~W}$ during the entire experiment. After a preconditioning phase, the last $50 \mathrm{~h}$ of this phase shown in Figure 10, an additional pseudo-random heat source of $\sim 196 \mathrm{~W}$ was switched on and off in the cell. This source was located inside the recirculation / conditioning apparatus (Figures 1 right and 2) and can, therefore, be considered as a purely convective heat load. Figure 10 also depicts eight air temperatures measured in different locations and heights in the cell and mean surface temperatures of all six faces as a function of time. During the experiment the measured air temperature stratification was less than $0.5 \mathrm{~K}$.

The time constant of the cell was determined by analyzing the temperature response of the cell to the first step increase of heating power and was found to be $17 \mathrm{~h}$.

\section{Simulation of transient experiment}

Four building energy simulation codes were used to model the transient experiment. These codes included DOE-2.1E, EnergyPlus, ESP-r and HELIOS. When the experiment was 
modeled, hourly averaged values of six outside cell envelope surface temperatures as boundary conditions and thermal power, including the pseudo-random heat source, were scheduled into the models. For all simulations, the thermophysical cell properties were taken from Tables 2, 3, 4, 5, 7 and 8 . As in most building energy simulation codes thermophysical properties cannot be defined as a function of temperature, constant values were therefore employed. The time-and-space averaged cell envelope temperature during the transient experiment of $28.38^{\circ} \mathrm{C}$ was used to calculate the thermal conductivities of the PU and EPS foam.

HELIOS $[18,25]$ was developed in the early 1980 s and has been recently upgraded. In this code, the thermal bridges were simulated by adding an additional heat transfer surface with a fictitious area to the zone that had the same layer sequence as the walls and the ceiling. This element employed the same thermal conductance as computed for the thermal bridges (Tab. 7). Because the thermal bridges were not located at one face, a mean outer surface temperature of all five faces was used. The thermal mass in the room was modeled as a $2 \mathrm{~mm}$ metal sheet using thermophysical properties of steel. HELIOS requires a constant value as input for the combined radiative and convective inside heat transfer coefficient. With regard to radiative heat transfer, view factors were calculated using the test cell geometry and assuming grey and diffuse inside cell surfaces. Because the surface temperatures in the cell were nearly the same at any given hour in this experiment, it could be shown that radiation is of very minor importance, and radiative heat transfer coefficient was therefore assumed to be zero. The convective heat transfer coefficients for the walls, ceiling and floor were taken according to ISO/WD 6946 [26].

The development of EnergyPlus began in 1996 by the US Department of Energy (DOE), and is described in detail by Crawley et al. [27]. Thermal bridges were simulated in this code by adding non-radiating surfaces to the back of the space with a constant outer cell surface temperature of $23.22^{\circ} \mathrm{C}$, which was the time-averaged outer cell surface temperature during the transient experiment. Because EnergyPlus calculates the radiation heat transfer using view factors and assuming gray and diffuse surfaces, six additional surfaces that faced each other were added to the model. For the other surfaces, a detailed approach was used to compute the convective heat transfer coefficient as a function of temperature difference between surface and cell air [28]. The thermal mass in the test cell was modeled in a similar way as in HELIOS.

The original version of DOE-2.1E was released in November 1993 by Lawrence Berkley Laboratories (LBL). To use the outer surface temperatures as boundary conditions, adjacent zones were created with a single zone air conditioner for each test cell surface. The zone temperature was scheduled as the outer cell surface temperature. The inside film resistance for these zones was specified as zero, thus making the adjacent zone temperature and the outer cell surface temperatures equal. For the inside of the test cell, numerical values of heat transfer coefficients were the same as in HELIOS. The thermal mass inside the cell was simulated by adding an equivalent amount of $0.139 \mathrm{~m}$ slab of EPS foam in the zone because using thermophysical properties of steel resulted in an error message.

ESP-r [17] is an open source program, developed by the Energy Systems Research Unit at the University of Strathclyde with input from many other organizations. It has been developed over a 28 year period. Full details of the underlying theory can be found in [1]. Because ESP$r$ requires a fully bounded zone, it was not possible to simulate the thermal bridges by simply adding additional surfaces connecting the internal air temperature with the external environment to represent the thermal bridges. Different approaches for modeling edge effects were tried, but the one giving the best agreement with measured data was the use of a "fin" added to the back of the test cell with a total surface area of $25.39 \mathrm{~m}^{2}$. This allowed the edge losses to be modeled without affecting the convective and radiative heat transfer from the 1-D heat transfer surfaces. Boundary temperatures were modeled by creating additional zones and imposing the measured temperatures. Several different convective 
regimes can be modeled by ESP-r, but the results presented here were based on the same convective coefficients as used in HELIOS. The thermal mass in the test cell was modeled as steel sheets in the room of appropriate dimensions.

A comparison plot between values of mean cell air temperature computed by all four codes is shown in Figure 11.

For HELIOS, discrepancies at the higher and lower temperatures were found that may mainly result from using a constant thermal conductivity (e.g. deviations tended to be smaller at the beginning and the end of the experiment, when a correct average envelope temperature of $26^{\circ} \mathrm{C}$ was used to calculate the thermophysical properties). Comparisons were made between the measured and predicted surface temperature for HELIOS. HELIOS under-predicted all cell surface temperatures. The wall surface temperatures were about $1 \mathrm{~K}$ lower at higher temperatures and $0.5 \mathrm{~K}$ lower at lower temperatures. Better agreement was seen at the ceiling where the temperature difference was about $0.3 \mathrm{~K}$ lower during the test. The largest discrepancies were seen when predicting the floor temperature; the error at high temperatures was nearly $3 \mathrm{~K}$ lower and at low temperatures was about $1 \mathrm{~K}$ lower.

For EnergyPlus, there were small discrepancies at the lower and higher temperatures. The deviations at lower temperatures may also be caused by using constant thermal conductivities for the PU and EPS foam. As in HELIOS, EnergyPlus under-predicted all the surface temperatures. The temperature differences for the walls were about $1 \mathrm{~K}$ at higher temperatures and $0.5 \mathrm{~K}$ at lower temperatures. The temperature differences for the floor during the experiment remained relatively constant at about $0.6 \mathrm{~K}$. At the ceiling, the temperature differences for the high temperatures and low temperatures were about $0.7 \mathrm{~K}$ and $0.3 \mathrm{~K}$, respectively. Large differences between surface temperatures for EnergyPlus and HELIOS were thought to be due to the selection (constant values were used in HELIOS and a temperature dependent algorithm was used in EnergyPlus) of convective heat transfer coefficients.

Similar discrepancies seen in the other simulations were also apparent in DOE-2.1E and ESP-r and are thought to come from assuming constant thermophysical and convective heat transfer coefficient properties. The surface temperature was not an available output in this version of DOE-2 and this model of ESP-r; comparisons between measured and predicted surface temperatures therefore could not be made.

\section{Statistical analysis of transient experiment results}

To quantitatively evaluate the measured and simulated air temperatures, a set of statistical and comparative quantities was chosen and will also be used in future work within this IEA project. The arithmetic mean, $\bar{x}$, maximum, $x_{\max }$, and minimum, $x_{\min }$, values and sample standard deviation, $s$, were computed for both the experimental and simulated results for all the 600 hours of the test.

To compare each simulation to the experiment, the differences between the experiment and the respective simulations, $D_{i}$ (where $i$ represents any given hour), were computed. The arithmetic mean, $\bar{D}$, maximum, $D_{\max }$, and minimum, $D_{\min }$, differences were determined for each simulation. The average absolute difference, $\mid \overline{|D|}$, was computed using Equation 6 . This quantity was used to show the overall magnitude of the difference between the simulations and the experiment.

$\overline{|D|}=\frac{1}{n} \sum_{i=1}^{n}\left|D_{i}\right|$ 
A root mean squared difference, $D_{r m s}$, was used to compare the experiment and the simulations shown in Equation 7. In this analysis larger deviations in the simulations for the experiment are weighted more for heavily; this quantity is essentially a standard deviation where the expected value would be zero.

$D_{r m s}=\sqrt{\frac{1}{n} \sum_{i=1}^{n} D_{i}^{2}}$

For additional comparisons, $95 \%$ quantiles, $D_{95 \%}$, using the absolute values of the temperature differences were computed for all simulations. Uncertainties associated with the average temperature calculation, $M U_{i}$, were calculated using propagation of error analysis (sometimes referred to as an uncertainty analysis) shown in Equation 8 to estimate the impact of measurement error in the individual air temperature measurements on the average air temperature calculation. The uncertainty in the individual air temperature measurements, $u_{i j}$, (where j represents an individual thermocouple) was taken from Tab. 11. For this analysis, all the partial derivatives reduced to $1 / \mathrm{m}$ (where $\mathrm{m}$ is the number of sensors).

$M U_{i}=\left(\sum_{j=1}^{m}\left(\frac{1}{m} u_{i j}\right)^{2}\right)^{1 / 2}=\frac{u_{i}}{\sqrt{m}}$

The uncertainties associated with the position of the sensors, $P U_{i}$, were estimated by taking the sample variance for the eight air temperature sensors at each hour. Because the

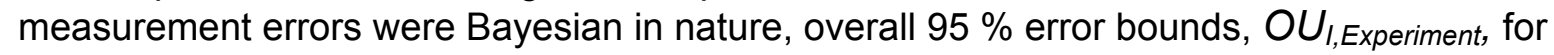
any given hour were estimated using Equation 9; the standard deviation for the measurement error was evaluated assuming a uniform distribution [29]. This analysis was done neglecting time-series interactions, which would also impact the overall uncertainty. The mean value, $\overline{O U}$, is reported in Table 13.

$O U_{i, \text { Experiment }}=1.96\left(P U_{i}+\frac{M U_{i}^{2}}{3}\right)^{1 / 2}$

An uncertainty analysis was performed in ESP-r using the Monte Carlo Analysis (MCA) to quantify overall output uncertainty for the building energy simulation codes due to uncertainties in input parameters. This analysis involves running a large number (100 in this study) of simulations. In each simulation, all input parameters are perturbed by a random selection of their input values assuming a normal distribution with the standard deviation set as in the above table. The advantage of MCA over a Differential Sensitivity Analysis (DSA), which is often used to quantify uncertainty due to input parameters, is that it does not assume linearity and parameter independence and, therefore, gives a more accurate measure of overall output uncertainty bands.

Ninety-five percent error bounds, $O U_{i, E S P-r}$, for each hour were also calculated and the mean quantity, $\overline{O U}$, is reported in Table 13 under the ESP-r column.

To compare the performance of the individual building energy simulation codes, an uncertainty ratio, $U R_{i}$, was devised to compare hourly differences with experimental and input errors and is shown in Equation 10. Mean, maximum and minimum uncertainty ratios are reported in Table 13. 
$U R_{i}=\frac{\left|D_{i}\right|}{O U_{i, E x p e r i m e n t}+O U_{i, E S P-r}}$

If UR $\leq 1$ then the agreement between the code and the experiment is within the $95 \%$ uncertainty bands given by the experimental uncertainty and the uncertainties of the input parameters. A summary of these statistics is shown in Table 13. A plot of the input uncertainties, experimental uncertainties, and the summation of these two quantities is shown in Figure 12.

A DSA using uncertainties provided in Table 2, 3, 4, 5, 7 and 8 revealed that computed cell air temperatures are most sensitive to (i) thermal bridge conductance, (ii) PU foam thermal conductivity, (iii) cell surface temperatures, (iv) overall cell dimensions, (v) EPS foam thermal conductivity, and (vi) PU foam thickness (ranking with decreasing importance).

\section{Conclusions and outlook}

If test cells are used for empirical validation of building energy simulation codes, determining the overall thermal cell characteristics is very important. Hence, the thermal properties of the Empa test cell were thoroughly analyzed both experimentally and numerically. Specifications were used as input parameters for modeling the cell in four building energy simulation codes. Taking into account the uncertainties of experimental data and those of computed cell air temperatures, it seems certain that specifications given in this paper adequately describe the transient thermal behavior of the Empa test cell. These results are a good foundation to begin investigating solar gains with and without internal and/or external window shadings. The data of the transient experiment is of high quality and can therefore be used by code developers and modelers for validation purposes.

To our knowledge, this study is the most detailed and comprehensive work - in terms of reliability of input data and boundary conditions - in the field of empirical validation of solar gain models in building energy simulation codes using test cells. The additional work in the Empa test cell in conjunction with the IEA Task 34/Annex 43 project includes a series of six experiments that are initially simple and increase in complexity. These six experiments include: (i) Glazing only, (ii) Glazing with external shading screens, (iii) Glazing with internal shading screens, (iv) Glazing with external venetian blinds, (v) Glazing with internal venetian blinds, and, (vi) Window (i.e. glazing with frames). The results from these experiments will be reported in future publications.

In view of the complexity and diversity of real building models and correspondingly huge parameter spaces, it is obvious that absolute validation of building energy simulation codes can never be achieved. However, high-quality empirical data remain absolutely essential for specific model and algorithm validations. Numerous modelers simulated the transient experiment presented in this paper using a number of different codes. These exercises have confirmed that modeling has to be done very carefully and that the modeler can also be a major source of deviations even for very simple models such as that of a cuboid shape test cell, where detailed information about all the input parameters are available, because thermal bridges or convective heat transfer at surfaces can be modeled differently. In addition to validation purposes, the provided data may also be valuable for educational purposes at universities and in engineering training courses.

Note: Data of the transient experiment (Exp. 2) and all subsequent experiments can be downloaded from our website at www.empa.ch/ieatask34.

\section{Acknowledgements}


We acknowledge with thanks the financial support of the Swiss Federal Office of Energy (BFE) for building and testing the experimental facility (Project 17'166) as well as the funding of Empa participation in IEA Task 34/43 (Project 100'765). R. Judkoff (NREL, USA) and numerous Task 34 participants provided valuable input for this project. We thank also our colleagues at Empa, B. Binder, R. Blessing, S. Carl, M. Christenson, C. Tanner and R. Vonbank for their contributions. We would also like to acknowledge the assistance provided by S. Vardeman at lowa State University for his valuable direction in the statistical analysis.

\section{References}

[1] Clarke JA. Energy simulation in building design. Oxford: Butterworth Heinemann; 2001.

[2] Judkoff RD. Validation of Building Energy Analysis Simulation Programs at the Solar Energy Research Institute. Energy and Buildings 1988; 10: 221-239.

[3] Judkoff RD, Neymark J. International Energy Agency Building Simulation Test (BESTEST) and Diagnostic Report, Report TP-472-6231. NREL, Golden CO; 1995.

[4] Ben-Nakhi AE, Aasem EO. Development and integration of a user friendly validation module within whole building dynamic simulation. Energy Conversion and Management 2003; 44 (1): 53-64.

[5] Jensen $S \varnothing$. Validation of building energy simulation programs: a methodology. Energy and Buildings 1995; 22: 133-144.

[6] Palomo Del Barrio E, Guyon G. Theoretical basis for empirical model validation using parameters space analysis tools, Energy and Buildings 2003; 35 (10): 985-996.

[7] Palomo Del Barrio E, Guyon G. Application of parameters space analysis tools for empirical model validation, Energy and Buildings 2004; 36 (1): 23-33.

[8] Bloomfield DP. An overview of validation methods for energy and environmental software. ASHRAE Transactions 1999; 685-693.

[9] Manz H, Frank T. Thermal simulation of buildings with double-skin façades. Energy and Buildings; accepted November 2004.

[10] Strachan P. Model Validation using the PASSYS Test Cells. Building and Environment 1993; 28: 153-165.

[11] Simmler H, Binder B, Vonbank R. Heat loads of transparent façade components and shading devices. Empa Materials Science \& Technology; 2000 (in German).

[12] Wouters $P$, Vandaele $L$, Voit $P$, Fisch N. The use of outdoor test cells for thermal and solar building research within the PASSYS project. Building and Environment 1993; 28: 107-113.

[13] Lomas KJ, Eppel H, Martin CJ, Bloomfield DP. Empirical validation of building energy simulation programs. Energy and Building 1997; 26: 253-275.

[14] Moinard S, Guyon G. Empirical Validation of EDF ETNA and GENEC Test-Cell Models. A Report of Task 22, Project A.3 Empirical Validation. International Energy Agency; 1999. 
[15] DOE-2.1E Software (Version-119). Building Energy Simulation Code. Lawrence Berkley Laboratories (LBL), Berkley CA; 2002.

[16] EnergyPlus Software (Version 1.2.0.029). Building Energy Simulation Code. http://www.energyplus.gov; 2004.

[17] ESP-r Software (Version 9). Building Energy Simulation Code. University of Strathclyde, Glasgow. http://www.esru.strath.ac.uk; 1999.

[18] HELIOS Software (Version 2000). Building Energy Simulation Code. Empa Materials Science \& Technology, Duebendorf, Switzerland; 2004.

[19] Lomas KJ, Eppel H. Sensitivity analysis techniques for building thermal simulation programs. Energy and Buildings 1992; 19: 21-44.

[20] Macdonald I, Strachan P. Practical application of uncertainty analysis. Energy and Buildings 2001; 33: 219-227.

[21] European Standard EN 410. Glass in building - Determination of luminous and solar characteristics of glazing. European Committee for Standardization, Brussels, Belgium; 1998.

[22] GLAD Software. Empa Materials Science \& Technology, Duebendorf, Switzerland; 2002.

[23] TRISCO (Version 10.0w). A computer program to calculate 3D steady-state heat transfer. Physibel, Heirweg 21, Maldegem, Belgium.

[24] prEN ISO 10077 - 2. Thermal performance of windows, doors and shutters Calculation of thermal transmittance - Part 2: Numerical method for frames (Final Draft). European Committee for Standardization, Brussels; 2003.

[25] Frank T. Manual HELIOS 1. NF-Project Report: Radiation Exchange at Building Surfaces. Empa Materials Science \& Technology, Duebendorf, Switzerland; 1982 (in German).

[26] EN ISO 6945. Building components and building elements - Thermal resistance and thermal transmittance - Calculation methods. Draft Revision. ISO; 2004.

[27] Crawey DB, Lawrie LK, Winkelmann FC, Buhl WF, Huang YJ, Pedersen CO, Strand RK, Liesen RJ, Fisher DE, Witte MJ, Glazer J. EnergyPlus: creating a newgeneration building energy simulation program. Energy and Buildings 2001; 33: 319331.

[28] EnergyPlus Engineering Document. The Reference to EnergyPlus Calculations. University of Illinois and LBL, 2004.

[29] Gleser LJ. Assessing Uncertainty in Measurement. Statistical Science 1998; 13: $277-$ 290. 
Table 1 Location of EMPA test cells.

\begin{tabular}{ll}
\hline Degree of longitude & $-8.6^{\circ}$ \\
Degree of latitude & $47.4^{\circ}$ \\
Altitude above sea-level & $430 \mathrm{~m}$ \\
Time zone & Greenwich Mean Time $(\mathrm{GMT})+1 \mathrm{~h}$ \\
Orientation of external wall & $29^{\circ}\left(\right.$ south $=0^{\circ}$, west $\left.=90^{\circ}\right)$ \\
\hline
\end{tabular}

Table 2 Geometrical parameters of test cell. Areas shown in this table are in contact with internal air.

Internal height

Internal width

Internal length

$2.360 \mathrm{~m} \pm 0.02 \mathrm{~m}^{\mathrm{b}}$

$2.850 \mathrm{~m} \pm 0.02 \mathrm{~m}^{\mathrm{b}}$

North / south wall

$4.626 \mathrm{~m} \pm 0.02 \mathrm{~m}^{\mathrm{b}}$

East / west wall

$6.726 \mathrm{~m}^{2} \pm 0.074 \mathrm{~m}^{2 \mathrm{a}}$

Floor / ceiling

$10.917 \mathrm{~m}^{2} \pm 0.104 \mathrm{~m}^{2 a}$

Internal volume

$13.184 \mathrm{~m}^{2} \pm 0.107 \mathrm{~m}^{2 a}$

$31.114 \mathrm{~m}^{3} \pm 0.368 \mathrm{~m}^{3 \mathrm{a}}$

$a$ is an estimate of error using propagation of error (uncertainty analysis) with individual Bayesian error estimates.

$b$ is a Bayesian estimate of error.

$c$ is a frequentist error which represents a sample standard deviation using literature values from different sources.

$d$ is an estimate of error using propagation of error (uncertainty analysis) with estimates of error from linear

regression analysis.

Table 3 Layer properties: Ceiling, north (incl. door), east and west wall.

\begin{tabular}{clcccc}
\hline $\begin{array}{c}\text { Layer } \\
\text { number }\end{array}$ & Material & $\begin{array}{c}\text { Thickness } \\
\mathrm{mm}\end{array}$ & $\begin{array}{c}\text { Thermal conductivity } \\
\mathrm{W} /(\mathrm{m} \mathrm{K})\end{array}$ & $\begin{array}{c}\text { Density } \\
\mathrm{kg} / \mathrm{m}^{3}\end{array}$ & $\begin{array}{c}\text { Specific heat } \\
\mathrm{J} /(\mathrm{kg} \mathrm{K})\end{array}$ \\
\hline 1 & Sheet steel & $0.7 \pm 0.1^{\mathrm{b}}$ & $53.62 \pm 6.56^{\mathrm{c}}$ & $7837 \pm 42^{\mathrm{c}}$ & $460.8 \pm 25.4^{\mathrm{c}}$ \\
2 & PU foam & $138.6 \pm 1^{\mathrm{b}}$ & $0.01921+0.000137 \cdot \theta \pm 6.5 \%{ }^{* \mathrm{~d}}$ & $30 \pm 0.3^{\mathrm{b}}$ & $1800 \pm 72^{\mathrm{b}}$ \\
3 & Sheet steel & $0.7 \pm 0.1^{\mathrm{b}}$ & $53.62 \pm 6.5^{\mathrm{c}}$ & $7837 \pm 42^{\mathrm{c}}$ & $4^{\mathrm{b}}$ \\
\hline
\end{tabular}

Own measurement, $\theta$ Temperature in degree Celsius

Table 4 Layer properties: Floor.

\begin{tabular}{|c|c|c|c|c|c|}
\hline $\begin{array}{l}\text { Layer } \\
\text { number }\end{array}$ & Material & $\begin{array}{c}\text { Thickness } \\
\mathrm{mm}\end{array}$ & $\begin{array}{c}\text { Thermal conductivity } \\
W /(m K)\end{array}$ & $\begin{array}{c}\text { Density } \\
\mathrm{kg} / \mathrm{m}^{3}\end{array}$ & $\begin{array}{c}\text { Specific heat } \\
\mathrm{J} /(\mathrm{kg} \mathrm{K})\end{array}$ \\
\hline 1 & Sheet steel & $0.7 \pm 0.1^{b}$ & $53.62 \pm 6.56^{\mathrm{c}}$ & $7837 \pm 42^{c}$ & $460.8 \pm 25.4^{c}$ \\
\hline 2 & PU foam & $140 \pm 1^{b}$ & $0.01921+0.000137 \cdot \theta \pm 6.5 \%{ }^{* d}$ & $30 \pm 0.3^{b}$ & $1800 \pm 72^{b}$ \\
\hline 3 & $\begin{array}{l}\text { PU foam (higher } \\
\text { density) }\end{array}$ & $20 \pm 0.5^{b}$ & $0.070 \pm 0.0035^{b}$ & $45 \pm 0.45^{b}$ & $1800 \pm 72^{b}$ \\
\hline 4 & $\begin{array}{l}\text { Sheet steel with surface } \\
\text { structure }\end{array}$ & $2.5 \pm 0.1^{b}$ & $53.62 \pm 6.56^{c}$ & $7837 \pm 42^{\mathrm{C}}$ & $460.8 \pm 25.4^{c}$ \\
\hline
\end{tabular}

Table 5 Layer properties: External Wall.

\begin{tabular}{|c|c|c|c|c|c|}
\hline $\begin{array}{l}\text { Layer } \\
\text { number }\end{array}$ & Material & $\begin{array}{c}\text { Thickness } \\
\mathrm{mm}\end{array}$ & $\begin{array}{c}\text { Thermal conductivity } \\
W /(m K)\end{array}$ & $\begin{array}{c}\text { Density } \\
\mathrm{kg} / \mathrm{m}^{3}\end{array}$ & $\begin{array}{l}\text { Specific heat } \\
\mathrm{J} /(\mathrm{kg} \mathrm{K})\end{array}$ \\
\hline 1 & Plywood & $10 \pm 0.5^{b}$ & $0.136359+0.000175 \cdot \theta \pm 2.5 \%{ }^{\mathrm{d} d}$ & $850 \pm 17^{b}$ & $1605 \pm 7.1^{b}$ \\
\hline 2 & EPS foam & $130 \pm 1^{b}$ & $0.03356+0.000127 \cdot \theta \pm 4.3 \%{ }^{* d}$ & $28 \pm 0.28^{b}$ & $1460 \pm 58.4^{b}$ \\
\hline 3 & Plywood & $10 \pm 0.5^{b}$ & $0.136359+0.000175 \cdot \theta \pm 2.5 \%{ }^{{ }^{\mathrm{d}}}$ & $850 \pm 17^{b}$ & $1605 \pm 7.1^{b}$ \\
\hline
\end{tabular}

Table 6 Optical properties of cell surfaces.

\begin{tabular}{lccc}
\hline & $\begin{array}{c}\text { Solar } \\
\text { reflectance }\end{array}$ & $\begin{array}{c}\text { Visible } \\
\text { reflectance }\end{array}$ & Emissivity \\
& - & - & - \\
\hline Inner surfaces of walls and ceiling & $0.757 \pm 1 \%$ & $0.874 \pm 1 \%$ & $0.92 \pm 5 \%$ \\
Inner surface of floor & $0.246 \pm 1 \%$ & $0.300 \pm 1 \%$ & $0.96 \pm 5 \%$ \\
Outer / inner surfaces of south wall & $0.766 \pm 1 \%$ & $0.884 \pm 1 \%$ & $0.93 \pm 5 \%$ \\
\hline
\end{tabular}


Table 7 Heat transfer coefficients and thermal conductances of cell to the guarded zone (cell air to outer surface of cell envelope).

\begin{tabular}{lccc} 
& Area & Heat transfer coefficient & \multicolumn{2}{c}{ Thermal conductance } \\
& $A$ & $\Lambda_{20^{\circ} \mathrm{C}}$ & $H_{20^{\circ} \mathrm{C}}$ \\
& $m^{2}$ & $W /\left(m^{2} \mathrm{~K}\right)$ & 6.478 \\
\hline Ceiling, north (incl. door), east and & 41.745 & 0.155 & 1.941 \\
west wall & & & $4.526 \pm 10 \%{ }^{\mathrm{b}}$ \\
Floor & 13.184 & - & 147.945 \\
Thermal bridges guarded zone & - & & 4.5
\end{tabular}

Table 8 Heat transfer coefficients and thermal conductances of cell to the outside (cell air to outer surface of cell envelope).

\begin{tabular}{lccc}
\hline & $\begin{array}{c}\text { Area } A \\
m^{2}\end{array}$ & $\begin{array}{c}\text { Heat transfer coefficient } \\
\Lambda_{20^{\circ} \mathrm{C}} \\
W /\left(m^{2} \mathrm{~K}\right)\end{array}$ & $\begin{array}{c}\text { Thermal conductance } \\
H_{20^{\circ} \mathrm{C}} \\
W / \mathrm{K}\end{array}$ \\
\hline External wall & 6.726 & 0.258 & 1.736 \\
Thermal bridges outside & - & - & $0.040 \pm 10 \%{ }^{\mathrm{b}}$ \\
\hline Total & & & 1.776 \\
\hline
\end{tabular}

Table 9 Sensitivity of thermal conductance to changes of important input parameters.

\begin{tabular}{lccc}
\hline Input parameter & Change of input parameter & \multicolumn{1}{c}{ Impact on thermal conductances } \\
& & $H_{G Z}$ & $H_{E W}$ \\
\hline Thermal conductivity of PU foam & $\pm 5 \%$ & $\pm 3.4 \%$ & - \\
Thermal conductivity of EPS foam & $\pm 5 \%$ & - & $\pm 4.7 \%$ \\
Thermal conductivity of steel & $\pm 10 \%$ & $\pm 0.3 \%$ & - \\
Thermal conductivity of stainless steel & $\pm 10 \%$ & $\pm 0.9 \%$ & - \\
\hline
\end{tabular}

Table 10 Weather data parameters and equipment.

\begin{tabular}{|c|c|c|c|c|}
\hline Parameter & Unit & Type of sensor / measurement & $\begin{array}{l}\text { Number of } \\
\text { sensors }\end{array}$ & Accuracy \\
\hline $\begin{array}{l}\text { Solar global irradiance, } \\
\text { façade plane }\end{array}$ & $\mathrm{W} / \mathrm{m}^{2}$ & Pyranometer (Kipp \& Zonen CM 21) & 1 & $\pm 2 \%$ \\
\hline $\begin{array}{l}\text { Solar global horizontal } \\
\text { irradiance }\end{array}$ & $\mathrm{W} / \mathrm{m}^{2}$ & Pyranometer (Kipp \& Zonen CM 21) & 1 & $\pm 2 \%$ \\
\hline $\begin{array}{l}\text { Solar diffuse horizontal } \\
\text { irradiance }\end{array}$ & $\mathrm{W} / \mathrm{m}^{2}$ & $\begin{array}{l}\text { Pyranometer, mounted under the } \\
\text { shading ball of a tracker (Kipp \& Zonen } \\
\text { CM 11) }\end{array}$ & 1 & $\pm 3 \%$ \\
\hline Direct-normal irradiance & $\mathrm{W} / \mathrm{m}^{2}$ & $\begin{array}{l}\text { Pyrheliometer, mounted in an } \\
\text { automatic sun-following tracker } \\
\text { (Kipp \& Zonen } \mathrm{CH} \text { 1) }\end{array}$ & 1 & $\pm 2 \%$ \\
\hline $\begin{array}{l}\text { Infrared irradiance, façade } \\
\text { plane }\end{array}$ & $\mathrm{W} / \mathrm{m}^{2}$ & Pyrgeometers (Kipp \& Zonen CG 4) & 1 & $\pm 2 \%$ \\
\hline $\begin{array}{l}\text { Outside air temperature, in } \\
\text { front of façade }\end{array}$ & ${ }^{\circ} \mathrm{C}$ & $\begin{array}{l}\text { Radiation shielded, mechanically } \\
\text { ventilated thermocouples }\end{array}$ & 2 & $\pm 0.5 \mathrm{~K}$ \\
\hline Wind speed, in front of façade & $\mathrm{m} / \mathrm{s}$ & Ultrasonic anemometer (WindMaster ) & 1 & $\pm 1.5 \%$ \\
\hline Horizontal illuminance & Lx & $\begin{array}{l}\text { Luxmeter (Kipp \& Zonen LuxLite, } \\
\text { Minolta T-10W) }\end{array}$ & 2 & $\pm 3 \%$ \\
\hline Pressure & $\mathrm{hPa}$ & $\begin{array}{l}\text { Barometric Pressure Measuring Device } \\
\text { (Vaisala PTA 427) }\end{array}$ & 1 & $\pm 0.5 \mathrm{hPa}$ \\
\hline Relative humidity & $\%$ & $\begin{array}{l}\text { Humidity Transmitter (Vaisala HMP } \\
\text { 130Y Series) }\end{array}$ & 1 & $\begin{array}{c} \pm 1 \%(0-90 \%) \\
\pm 2 \%(90-100 \%) \\
\end{array}$ \\
\hline
\end{tabular}


Table 11 Parameters measured in the test cell, the external chamber and the guarded zone and approximate accuracies according to manufacturer specifications.

\begin{tabular}{|c|c|c|c|c|}
\hline Parameter & Unit & Type of sensor / measurement & $\begin{array}{l}\text { Number of } \\
\text { sensors }\end{array}$ & Accuracy \\
\hline Air temperatures, inside test cell & ${ }^{\circ} \mathrm{C}$ & $\begin{array}{l}\text { Thermocouple, radiation shielded by } \\
\text { two cylinders }\end{array}$ & 8 & $\pm 0.3 \mathrm{~K}$ \\
\hline Air temperatures, in external chamber & ${ }^{\circ} \mathrm{C}$ & $\begin{array}{l}\text { Thermocouple, radiation shielded by } \\
\text { two cylinders }\end{array}$ & 5 & $\pm 0.3 \mathrm{~K}$ \\
\hline $\begin{array}{l}\text { Air temperatures, in guarded zone, } 0.1 \\
\mathrm{~m} \text { in front of cell surface }\end{array}$ & ${ }^{\circ} \mathrm{C}$ & $\begin{array}{l}\text { Thermocouple, radiation shielded by } \\
\text { two cylinders }\end{array}$ & 25 & $\pm 0.3 \mathrm{~K}$ \\
\hline $\begin{array}{l}\text { Surface temperatures, inner surface of } \\
\text { cell envelope }\end{array}$ & ${ }^{\circ} \mathrm{C}$ & Thermocouple & 30 & $\pm 0.3 \mathrm{~K}$ \\
\hline $\begin{array}{l}\text { Surface temperatures, outer surface of } \\
\text { cell envelope }\end{array}$ & ${ }^{\circ} \mathrm{C}$ & Thermocouple & 30 & $\pm 0.3 \mathrm{~K}$ \\
\hline Heating power, inside test cell & W & Electric power (Infratek 106A) & 1 & $\pm 0.1 \%$ \\
\hline Cooling power, inside test cell & W & $\begin{array}{l}\text { Electromagnetic flowmeter } \\
\text { (Endress+Hauser Promag 53H) and } \\
\text { temperature difference } \\
\text { measurement (PT100) }\end{array}$ & 3 & $\pm 2 \%$ \\
\hline Illuminance, horizontal inside cell & Lx & Luxmeter (Minolta T-1H) & 3 & $\pm 2 \%$ \\
\hline
\end{tabular}

Table 12 Steady-state experiment: Time-averaged values and uncertainties for thermal conductance calculations.

\begin{tabular}{lcccc}
\hline & $P_{e l}$ & $T_{T C}$ & $T_{G Z}$ & $T_{E C}$ \\
\hline Phase A & $282.26 \mathrm{~W} \pm 4 \mathrm{~W}$ & $43.13^{\circ} \mathrm{C} \pm 0.5^{\circ} \mathrm{C}$ & $23.50^{\circ} \mathrm{C} \pm 0.5^{\circ} \mathrm{C}$ & $23.24^{\circ} \mathrm{C} \pm 0.5^{\circ} \mathrm{C}$ \\
Phase B & $145.04 \mathrm{~W} \pm 3 \mathrm{~W}$ & $36.45^{\circ} \mathrm{C} \pm 0.5^{\circ} \mathrm{C}$ & $23.33^{\circ} \mathrm{C} \pm 0.5^{\circ} \mathrm{C}$ & $43.74^{\circ} \mathrm{C} \pm 0.5^{\circ} \mathrm{C}$ \\
\hline
\end{tabular}

Table 13 A summary of the descriptive and comparative statistics.

\begin{tabular}{cccccc}
\hline Parameter & Experiment & Helios & EnergyPlus & DOE-2.1e & ESP-r \\
\hline $\bar{x}$ & $33.55^{\circ} \mathrm{C}$ & $33.44{ }^{\circ} \mathrm{C}$ & $33.41{ }^{\circ} \mathrm{C}$ & $33.48{ }^{\circ} \mathrm{C}$ & $33.18^{\circ} \mathrm{C}$ \\
$s$ & $4.89 \mathrm{~K}$ & $5.05 \mathrm{~K}$ & $4.94 \mathrm{~K}$ & $5.00 \mathrm{~K}$ & $4.97 \mathrm{~K}$ \\
$x_{\max }$ & $42.3^{\circ} \mathrm{C}$ & $42.54{ }^{\circ} \mathrm{C}$ & $42.33^{\circ} \mathrm{C}$ & $42.6^{\circ} \mathrm{C}$ & $42.19^{\circ} \mathrm{C}$ \\
$x_{\min }$ & $28.65{ }^{\circ} \mathrm{C}$ & $28.48{ }^{\circ} \mathrm{C}$ & $28.57{ }^{\circ} \mathrm{C}$ & $28.5^{\circ} \mathrm{C}$ & $28.37{ }^{\circ} \mathrm{C}$ \\
$\bar{D}$ & - & $0.11 \mathrm{~K}$ & $0.14 \mathrm{~K}$ & $0.06 \mathrm{~K}$ & $0.36 \mathrm{~K}$ \\
$\overline{\mid D}$ & - & $0.31 \mathrm{~K}$ & $0.18 \mathrm{~K}$ & $0.25 \mathrm{~K}$ & $0.37 \mathrm{~K}$ \\
$D_{\max }$ & - & $0.8 \mathrm{~K}$ & $0.72 \mathrm{~K}$ & $1.22 \mathrm{~K}$ & $0.94 \mathrm{~K}$ \\
$D_{\min }$ & - & $0.01 \mathrm{~K}$ & $0.00 \mathrm{~K}$ & $0.00 \mathrm{~K}$ & $0.01 \mathrm{~K}$ \\
$D_{r m s}$ & - & $0.34 \mathrm{~K}$ & $0.24 \mathrm{~K}$ & $0.33 \mathrm{~K}$ & $0.42 \mathrm{~K}$ \\
$D_{95 \%}$ & - & $0.62 \mathrm{~K}$ & $0.50 \mathrm{~K}$ & $0.73 \mathrm{~K}$ & $0.72 \mathrm{~K}$ \\
$\overline{O U}$ & $0.26 \mathrm{~K}$ & - & - & - & $1.17 \mathrm{~K}$ \\
$\overline{U R}$ & - & 0.24 & 0.14 & 0.2 & 0.29 \\
$U R_{\max }$ & - & 0.8 & 0.6 & 1.16 & 0.65 \\
$U R_{\min }$ & - & 0.01 & 0 & 0 & 0.01 \\
\hline
\end{tabular}



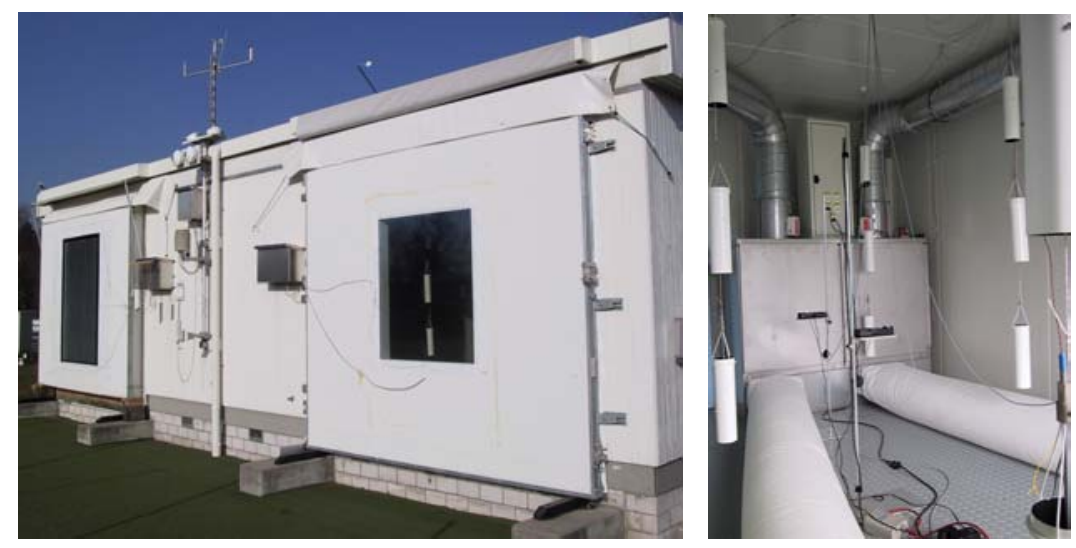

Fig. 1 Outdoor view (left) of test cells with two removable façade elements $(3.4 \mathrm{~m} \times 3.4 \mathrm{~m}$ ) and indoor view (right) showing HVAC cabinet and extract and supply ducts.

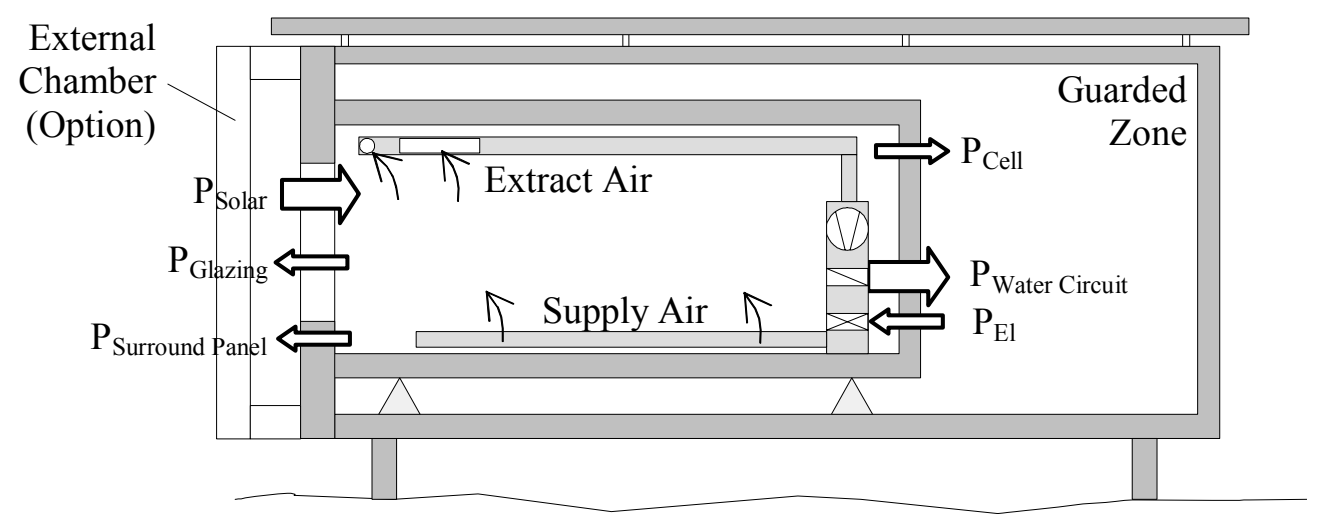

Fig. 2 Concept of test facility with air conditioning of the cell, guarded zone, energy flows into and out of the test cell and optional external chamber.
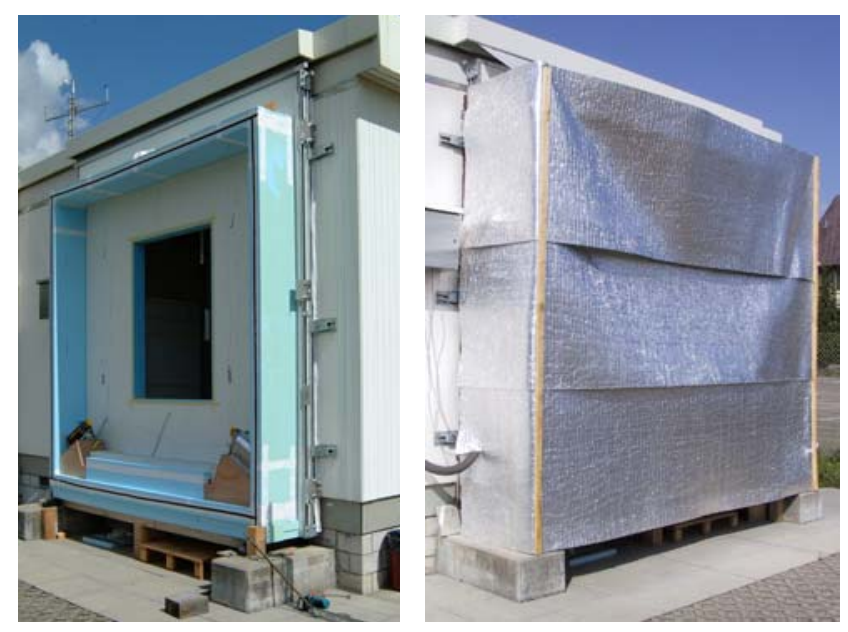

Fig. 3 Thermally controlled external chamber mounted in front of one of the cells and viewed from outside during (left) and after construction (right). 


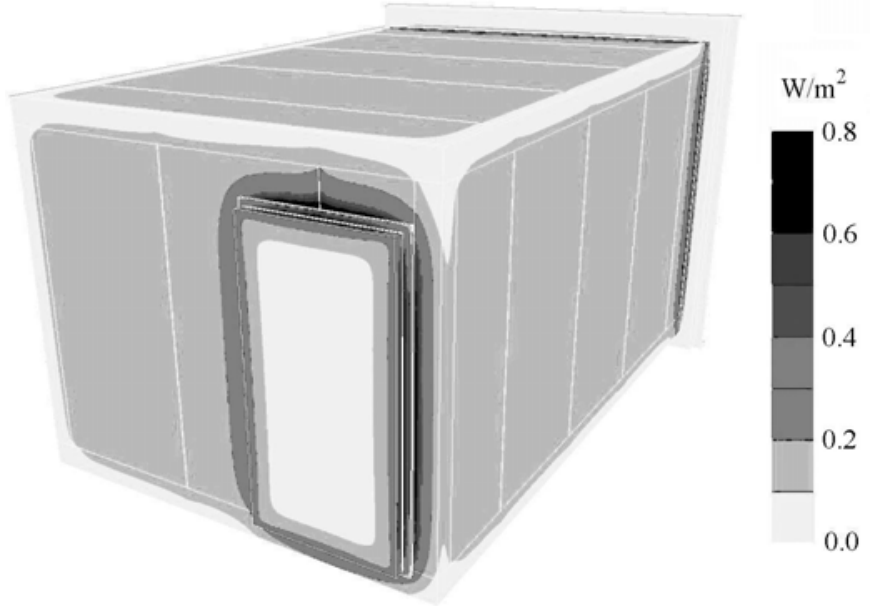

Fig. 4 Computed heat fluxes at the outer surfaces of the test cell at a temperature difference of $1 \mathrm{~K}$ between cell air and guarded zone.

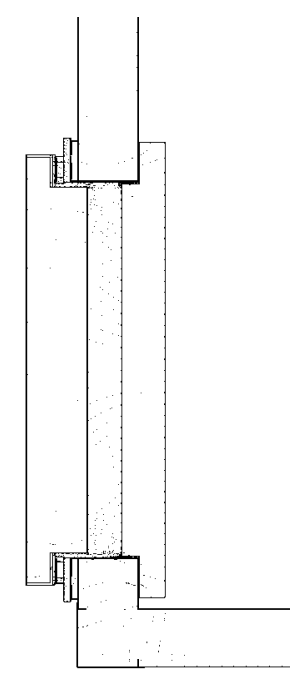

Fig. 5 Computed heat fluxes in a horizontal cross-section of the door.

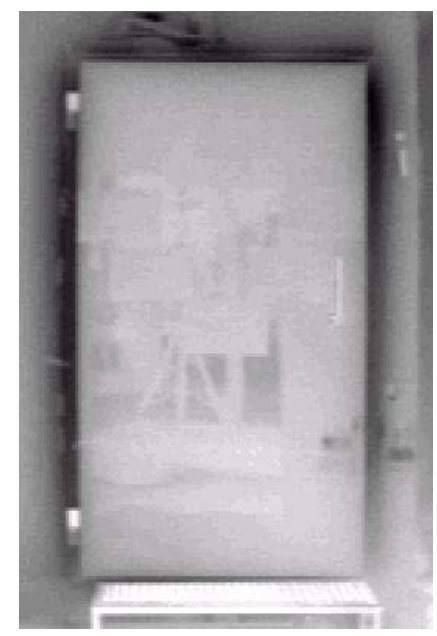

Fig. 6 Infrared picture of the cell door, taken when temperature in the cell was $20 \mathrm{~K}$ higher than in the guarded zone, shows thermal bridges at the door frame. 


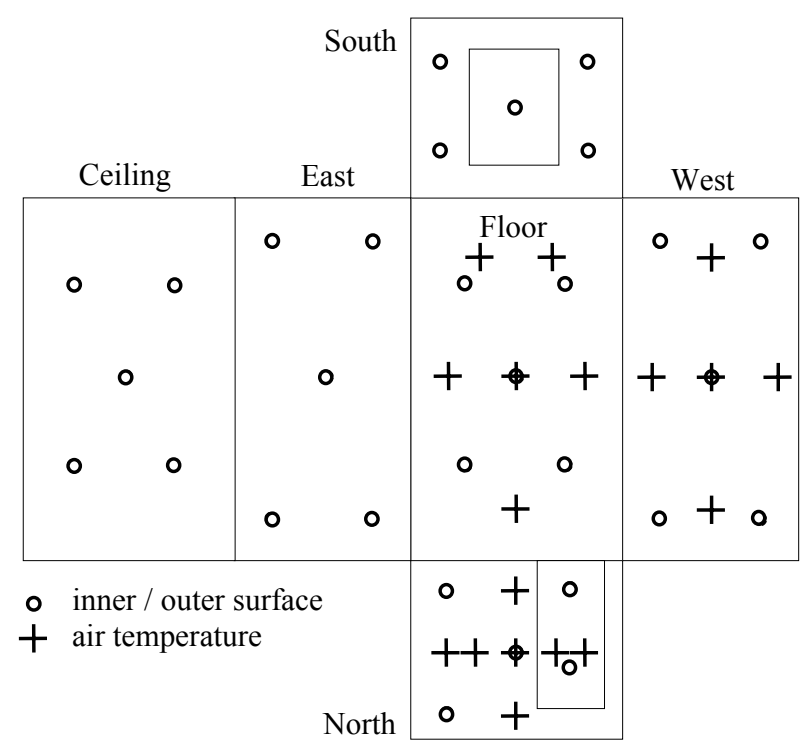

Fig. 7 Location of temperature sensors on inner (30 sensors) and outer (30 sensors) surface of cell envelope. For air temperature (8 sensors) projections on floor, north and west wall are shown.

Temperatures:
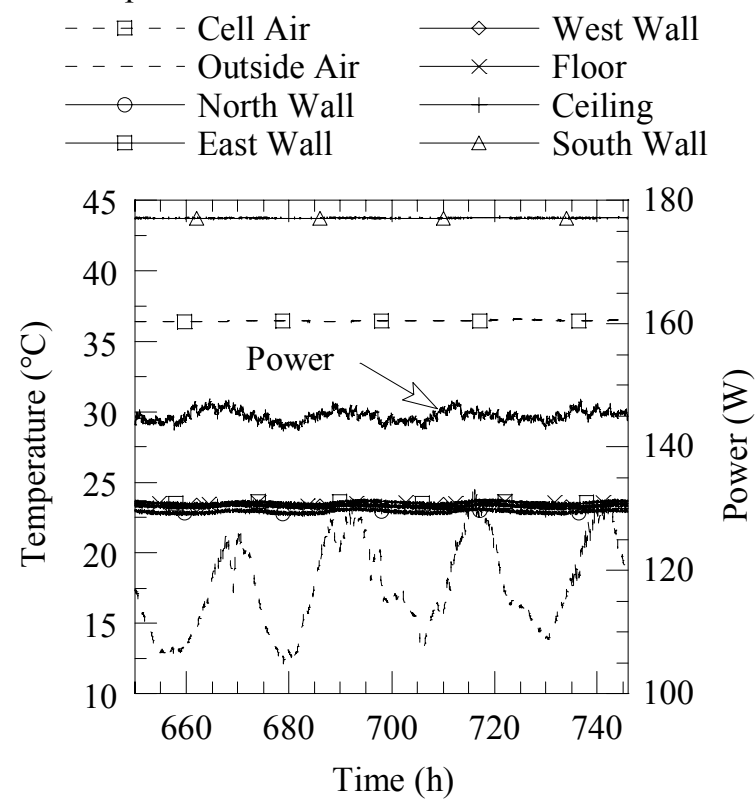

Fig. 8 Mean air temperature inside cell and outside, mean surface temperatures of all six faces and heating power inside the cell as a function of time during phase $B$ of the steadystate experiment (duration $96 \mathrm{~h}$ ). 


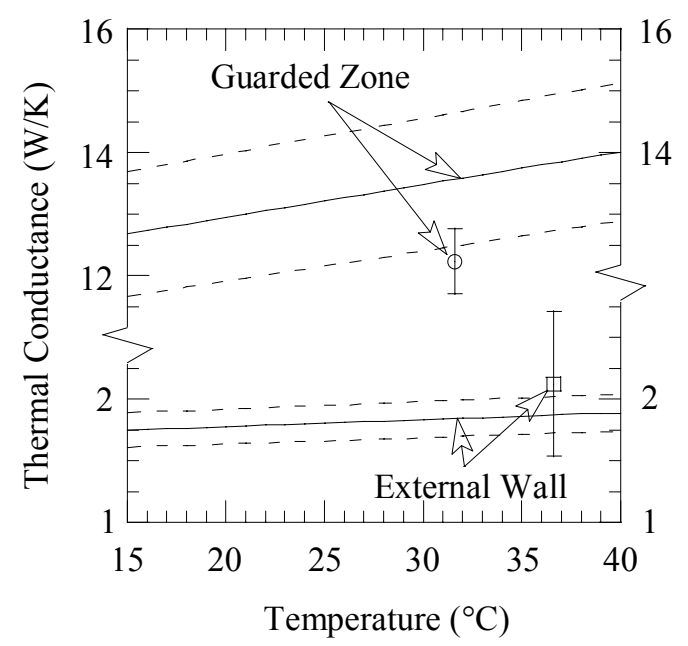

Fig. 9 Comparison of thermal conductances $H_{G Z}$ and $H_{E W}$ as function of temperature found by simulation and the steady-state experiment.

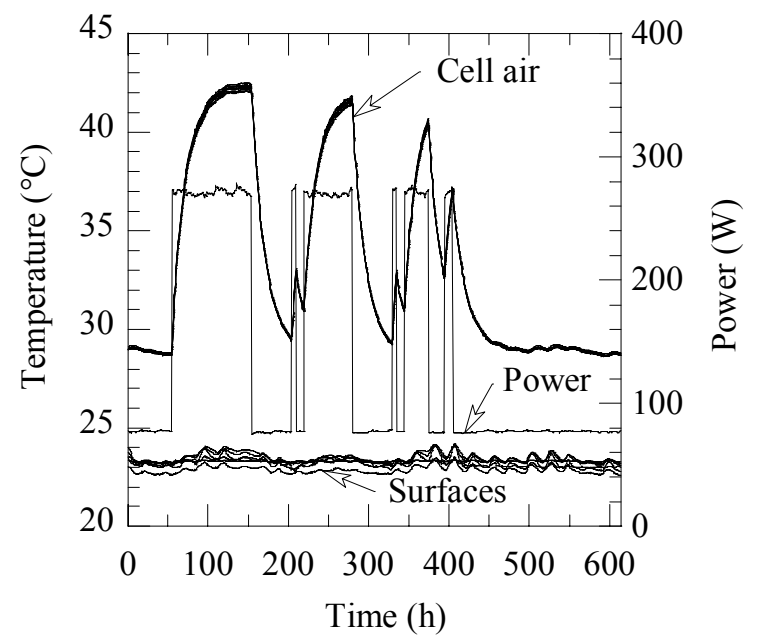

Fig. 10 Measured pseudo-random internal heating power, cell air temperatures (total eight sensors) and mean surface temperatures of all six outer cell surfaces.

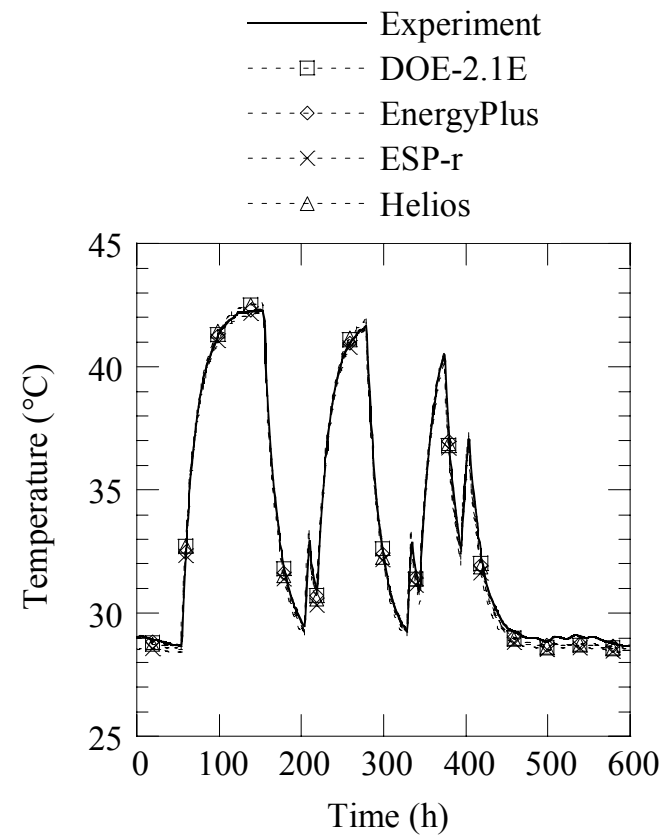

Fig. 11 Cell air temperatures simulated by three different codes and experimental uncertainty band of $\pm 0.3 \mathrm{~K}$ for the transient experiment. 


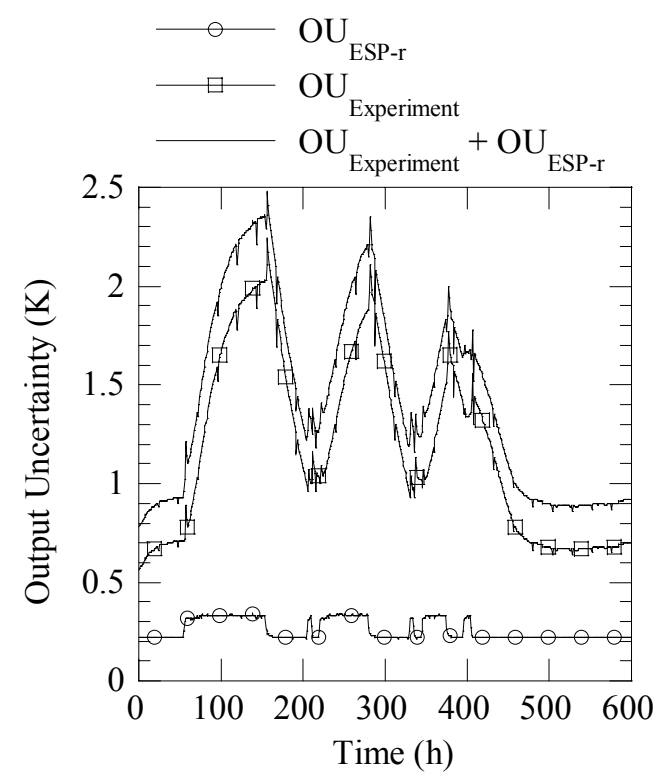

Fig. 12 Experimental uncertainty, uncertainty of simulation results due to uncertainty in input parameters and total uncertainty. 